\title{
Artificial dam lakes as suitable habitats for exotic invertebrates: Ostracoda ecology and distribution in reservoirs of the Eastern Iberian Peninsula
}

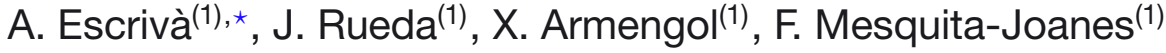 \\ Received September 19, 2013 \\ Revised December 4, 2013 \\ Accepted December 5, 2013
}

Key-words: ostracoda, exotic species, reservoirs, Spain, benthos

\section{ABSTRACT}

Reservoirs are the most common deep lakes in Spain, as a consequence of water needs and dry climate. Although these aquatic systems can play an important ecological role in such an area with few large natural lakes, they can also provide new habitats for exotic species, which can colonize ecosystems that native species have not explored yet. Here we present our results for a biannual survey of the ostracod fauna from 24 reservoirs in Xúquer River basin. We check which variables affect ostracod presence, test for differences between winter and summer assemblages, and compare our data with previous available ostracod records from the same river drainage network. Our results reveal that ostracod presence is positively related to high diversity of the invertebrate community and reservoir volume, and negatively with phosphorus concentration. Among the 22 species found, it is noteworthy the first Iberian record of llyocypris getica and the second European record of Candonocypris novaezelandiae. Ostracod assemblages significantly vary between summer and winter, and strong differences are found between ostracod communities of reservoirs and those from their connected rivers. Remarkably higher frequency of exotic species in the reservoirs confirms previous findings about the facilitation that artificial ecosystems confer to aquatic invasions.

\section{RÉSUMÉ}

Les lacs de barrage comme habitats appropriés pour les invertébrés exotiques : écologie et distribution des ostracodes dans les réservoirs dans l'Est de la péninsule ibérique

Mots-clés : ostracodes, espèces exotiques, réservoirs, Espagne, benthos
Les réservoirs sont les plus courants lacs profonds en Espagne, en réponse aux besoins en eau et au climat sec. Bien que ces systèmes aquatiques puissent jouer un rôle écologique important dans une région avec peu de grands lacs naturels, ils peuvent aussi fournir de nouveaux habitats pour les espèces exotiques, qui peuvent coloniser ces écosystèmes que les espèces indigènes n'ont pas encore explorés. Ici, nous présentons les résultats d'un suivi semestriel de la faune d'ostracodes de 24 réservoirs dans le bassin de la rivière Xúquer. Nous recherchons quelles variables affectent la présence des ostracodes, testons les différences entre les assemblages d'hiver et d'été, et comparons nos données avec des données antérieures d'ostracodes disponibles du même bassin versant. Nos résultats révèlent que la présence des ostracodes est positivement liée à la grande diversité

(1) Departament de Microbiologia i Ecologia/Institut Cavanilles de Biodiversitat i Biologia Evolutiva, Universitat de València, Spain

* Corresponding author: andreu.escriva@uv.es 
de la communauté d'invertébrés et au volume du réservoir, et négativement avec la concentration en phosphore. Parmi les 22 espèces présentes, il est à noter le premier enregistrement ibérique de llyocypris getica et le deuxième d'Europe de Candonocypris novaezelandiae. Les assemblages d'ostracodes varient considérablement entre l'été et l'hiver, et de fortes différences sont observées entre les communautés d'ostracodes de réservoirs et celles de leurs rivières tributaires. Une fréquence remarquablement élevée d'espèces exotiques dans les réservoirs confirme des conclusions précédentes sur la facilitation que les écosystèmes artificiels confèrent aux invasions aquatiques.

\section{INTRODUCTION}

Reservoirs represent an extreme modification of rivers, changing the hydric regime from lotic to lentic, what implies a deep alteration of their limnological characteristics, which also differ from a natural lake. Dam construction disturbs the previously established flora and fauna, as it usually implies water eutrophication (Moss, 1998). Furthermore, most of the substrate area for the new waterbody has never been linked to the aquatic environment (as usually they are not floodplains, but heavy mountain slopes), and the shore level shifts rapidly not because of the natural water cycle but strongly depending on human demand. All these factors highly affect the reservoirs' ecology, making them unique habitats and, in the case of Spain, what Margalef (1983) described as an "ecological experiment". Indeed, Spain presents a high degree of human-control and channel modifications of rivers due to the Mediterranean climate, which triggers low availability of water for agriculture and human use during long periods (from months to years) (Aupí, 2005).

Biological invasions are frequent in reservoirs, as they are relatively new, disturbed, manmanaged habitats (Moss, 1998; Havel et al., 2005). In the lberian Peninsula, most of known introduced aquatic species are fishes, which arrive to the reservoirs both form accidental and deliberate introductions (Elvira, 1995). Some of these species are able to produce great disturbances and become dominant, like the black bass, Micropterus salmoides (Lacépède, 1802) (Elvira, 1995). Aquatic invertebrate invasions, although not as noticeable as vertebrate's, are becoming increasingly common (Gherardi, 2007). In Spain, the zebra mussel Dreissena polymorpha (Pallas, 1771) is the best-known case, because of its enormous ecological and economic impact (Durán et al., 2009, 2012). This invasive species is present in the Ebro and Xúquer basins and it is still spreading, mainly because of the fishing-related transport (boats, shoes, car tires), even though several control measures are strict and operative in all the territory where it is found (Durán Lalaguna and Anadón Marco, 2008). Other examples of aquatic invasive invertebrates in the area are the American crayfish Procambarus clarkii (Girard, 1852) (which is widespread and not only related to reservoirs but to all kind of water systems) and molluscs such as the snail Pomacea insularum (d'Orbigny, 1835), which produces large ecological and agricultural disturbances in the Ebro Delta, or the clam Corbicula fluminea (Müller, 1774) (Geiger et al. 2005; Pérez-Quintana, 2008; MMAMRM, 2011).

Although riverine ostracods in eastern Spain have been studied before (Mezquita et al., 1999, 2001), there is not any comprehensive survey of this widespread crustacean group in Iberian or European reservoirs hitherto. In our broad survey, we aimed at contributing to the knowledge of exotic ostracod species, which have been poorly reported from Spanish freshwater ecosystems (Forés et al., 1986, Escrivà et al., 2012). Despite reservoirs are physically connected to their associated rivers, they should be considered disparate ecosystems, and therefore we expected to found wide differences in ostracod assemblages between them. In this framework, one of our main scopes was to test the hypothesis that ostracod communities would differ between reservoirs and rivers, and a higher number of exotic species is expected in the artificial impoundment lakes, as they have been described as "stepping stones" for invasive species (Havel et al., 2005). 


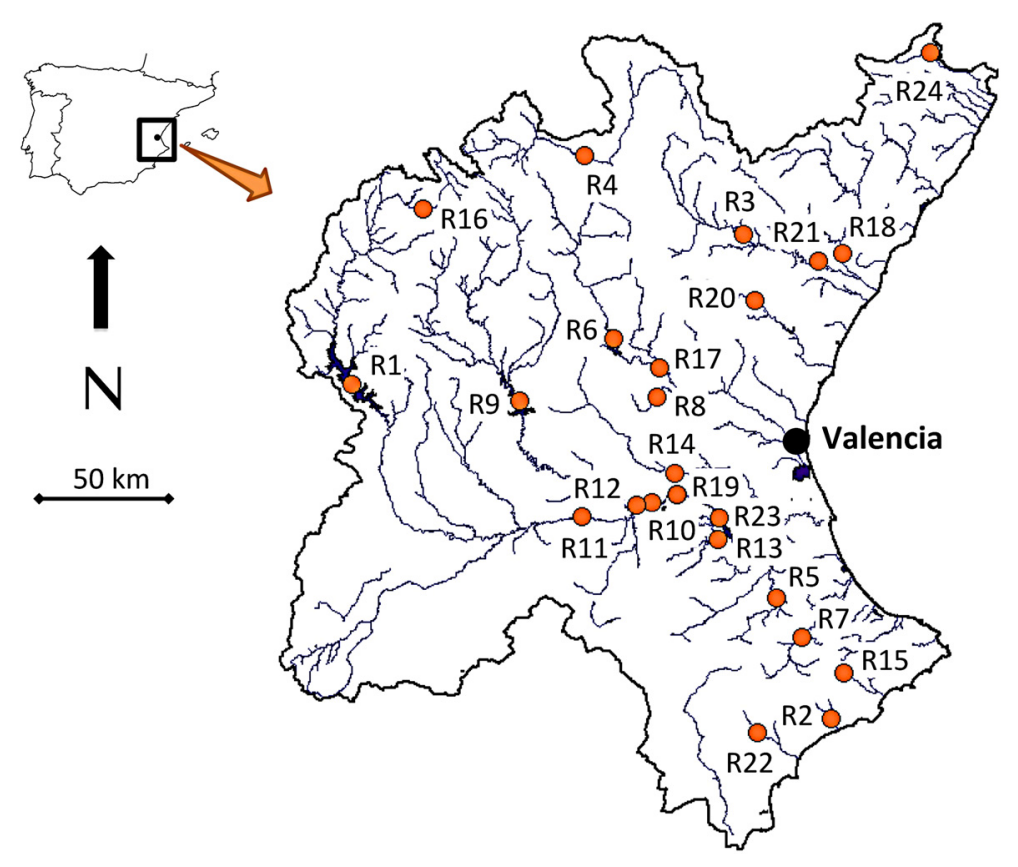

Figure 1

Map of the study area showing sampling locations. Codes for reservoirs are the same as in Table II.

\section{MATERIALS AND METHODS}

We analysed the ostracod communities of 24 reservoirs (Figure 1) managed by the Xúquer River Basin Hydrological Administration (CHJ, Confederación Hidrográfica del Júcar). This management unit covers $48832 \mathrm{~km}^{2}$ on the central slope of the Eastern Iberian Peninsula, encompassing Xúquer (=Júcar) and Túria rivers as the two largest basins in this unit. The geography of the area consists mainly of an extensive Quaternary alluvial plain surrounded by limestone massifs reaching almost $2000 \mathrm{~m}$ a.s.l. The climate is mainly Mediterranean, with rainfall concentrated in spring and autumn, and summer drought affecting almost all the rivers and generating a considerable ecological stress to the riparian vegetation and fauna inhabiting the banks and riverbeds (Aupí, 2005)

All reservoirs were sampled on 4 occasions: summer 2006, winter 2006/2007, summer 2007 and winter 2007/2008, with the only exception of Guadalest (R15) that was not sampled in winter 2007/2008. All of the acquired samples (95) were collected using an Ekman dredge ( $0.0225 \mathrm{~m}^{2}$ sampled once), from a boat located in the central area of the reservoir, but always at depths ranging between 3 and $5 \mathrm{~m}$ to avoid hypoxic layers. The samples were preserved with dilute formaldehyde (4\%) in the field, and then washed (mesh size $=200 \mu \mathrm{m}$ ) and preserved in ethanol $(70 \%)$ in the laboratory. Macroinvertebrates and ostracods were identified with a stereomicroscope and light microscopy using Meisch (2000) for Ostracoda and Tachet et al. (2000) for macroinvertebrates. Pictures of ostracod valves and carapaces were taken with a Philips XL30 scanning electron microscope (SEM) at the University of Valencia, after their coating with Au-Pd.

Physical and chemical data from reservoirs, collected at the same time than the biological samples, were downloaded from the Spanish Ministry of Agriculture, Food and Environment, through its $\mathrm{CHJ}$ webpage (www.chj.es). These variables included altitude $(\mathrm{m})$, depth $(\mathrm{m})$ and volume $\left(\mathrm{hm}^{3}\right)$; water temperature $\left({ }^{\circ} \mathrm{C}\right)$, conductivity $\left(\mu \mathrm{S} \cdot \mathrm{cm}^{-1}\right), \mathrm{pH}$, oxygen content $\left(\mathrm{mg} \cdot \mathrm{L}^{-1}\right)$ and saturation percentage and turbidity (NTU), measured in situ with portable probes as an average of the water column; Secchi disc depth $(\mathrm{m})$; chlorophyll a $\left(\mu \mathrm{g} \cdot \mathrm{L}^{-1}\right)$, nitrite, nitrate, ammonia, total nitrogen, ortophosphate and total phosphorus concentrations $\left(\mathrm{mg} \cdot \mathrm{L}^{-1}\right)$ and algal biovolume $\left(\mathrm{mm}^{3} \cdot \mathrm{L}^{-1}\right)$ measured in the lab from water samples collected at $2 \mathrm{~m}$ depth. 
Macroinvertebrate Shannon diversity index $(\mathrm{H}$, with log base 2) was calculated from the identified taxa obtained with the dredge. From the same samples, presence, absence and abundances of ostracod taxa were obtained. For statistical comparisons, ostracod data from associated rivers was acquired from the only comprehensive work published on the ostracod fauna of the basins sampled in the present survey (Mezquita et al., 1999).

In order to check for environmental effects on the presence of living ostracods we performed a binary multivariate logistic regression (LR) with stepwise forward selection of variables, using the software SPPS v19.0 (SPPS Inc., 2010). In LR we introduced the above mentioned predictor variables. With the exceptions of temperature, diversity, altitude, depth, Secchi Disc and oxygen saturation percentage, the rest of variables were $\log _{10}$-transformed because they presented a right-skewed distribution.

We performed Analyses of Similarities (ANOSIM) and Similarity Percentage (SIMPER) analyses (Clarke and Warwick, 2001) to compare the ostracod communities (presence-absence data) between winter and summer seasons and between reservoirs and rivers. Both were carried out using the Jaccard index in PAST software (Hammer et al., 2001). The relationship between ostracod assemblages (presence-absence) and environmental data was studied using CANOCO for Windows (ter Braak and Šmilauer, 2002). We performed a DCCA in order to evaluate the length of the gradient; as we obtained a value higher than 4 , we decided to use a CCA unimodal analysis (with downweighting of rare species) following Lepš and Šmilauer (2003). The forward selection of variables (FSV) with 999 permutations was used to select the most relevant parameters explaining ostracod species distribution.

\section{RESULTS}

In the 95 samples from 24 reservoirs we found a total of 351 individuals accounting for 22 species of ostracods (Table I). The most common species were llyocypris gibba and Darwinula stevensoni. llyocypris getica was here found for the first time on the Iberian Peninsula and the presence of two exotic species (Fabaeformiscandona subacuta and Candonocypris novaezelandiae) was also remarkable. SEM photographs of selected species are shown in Figure 2.

A total number of 43 taxa of macroinvertebrates were found. These data were used to calculate Shannon diversity as a proxy for reservoirs' ecological state (shown in Table II), taking into account that increasing stress in reservoirs through level variations and eutrophic conditions reduces benthic diversity (Margalef, 1983). Two exotic species were detected: the zebra mussel Dreissena polymorpha, found abundantly in one reservoir (R21), and the crayfish Procambarus clarkii, that was found in reservoirs R11 and R19. Further detailed discussion of the invertebrate data will be published elsewhere.

As can be seen in Table II, the studied reservoirs have a broad range of physical, chemical and biological conditions. Altitude ranges between 106 and $1156 \mathrm{~m}$ a.s.I., and volume between 4 and $1118 \mathrm{hm}^{3}$. Conductivity varies an order of magnitude, from a minimum measured value of 308 to a maximum of $3228 \mu \mathrm{S} \cdot \mathrm{cm}^{-1}$; the macroinvertebrate Shannon diversity index ranged from a minimum observed value of 0 (no taxa found) to a maximum value of 2.99 bits $\cdot$ ind.$^{-1}$.

According to logistic regression analysis, the presence of living ostracods (found in 40 out of 95 samples) is positively related to macroinvertebrate diversity and reservoir volume, and negatively to total phosphorus concentration. The final model with these three variables included was significant $\left(p<0.001 ; R^{2}=0.29\right)$ and allowed a correct classification of $74 \%$ of samples according to the presence or absence of living ostracods.

An ANOSIM analysis was performed comparing the ostracod fauna (occurrence data) between reservoirs and rivers. Here, dead specimens (i.e. valves and other remaining parts of ostracod individuals) were considered as "presence" to account for inter-annual variability in ostracod assemblages. This analysis shows that these two habitats can be clearly separated because of their ostracod fauna $(R=0.3764, p=0.0001)$. A SIMPER analyses was performed to identify the main species that differed between each habitat. The mean rank 


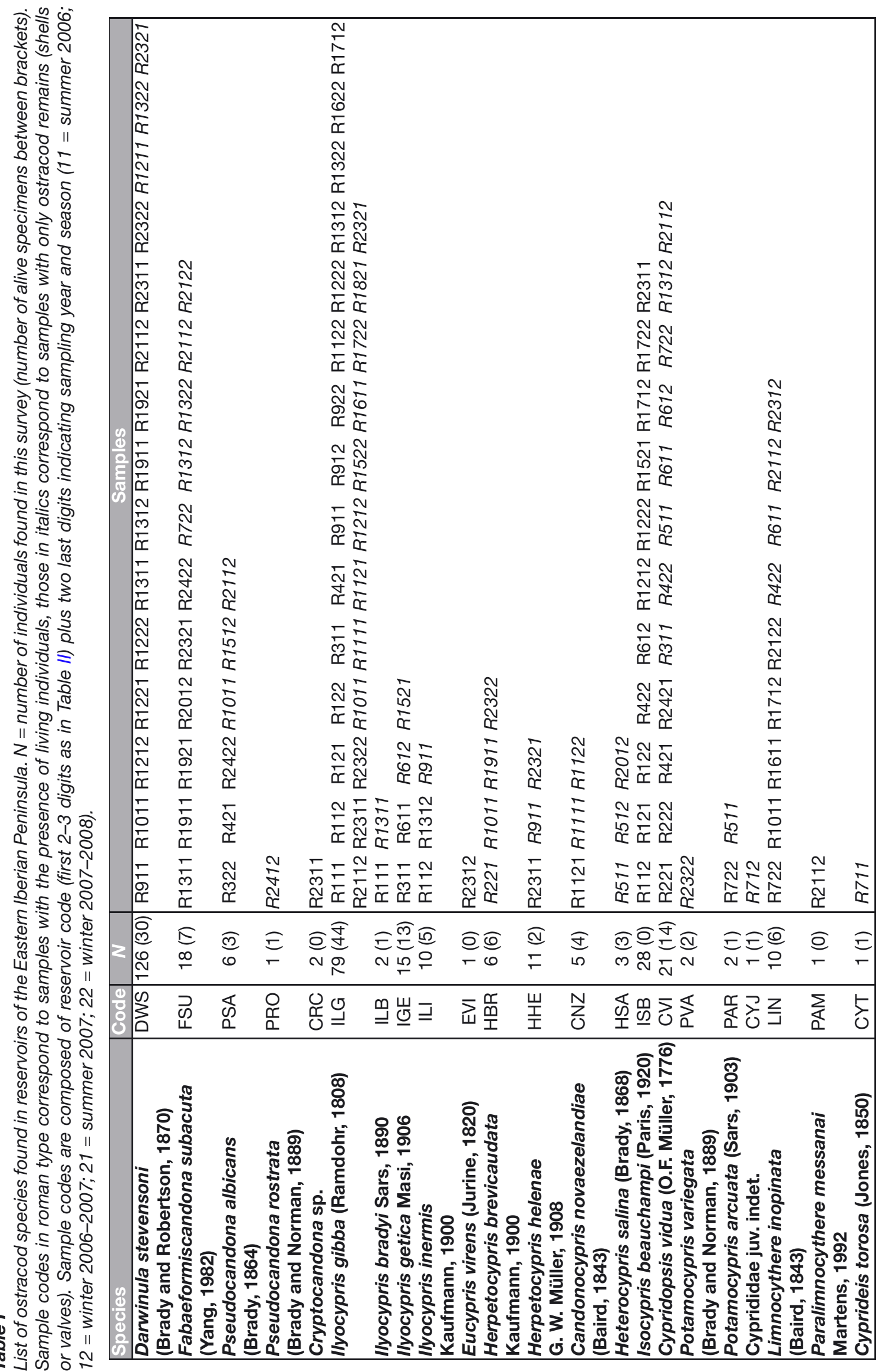




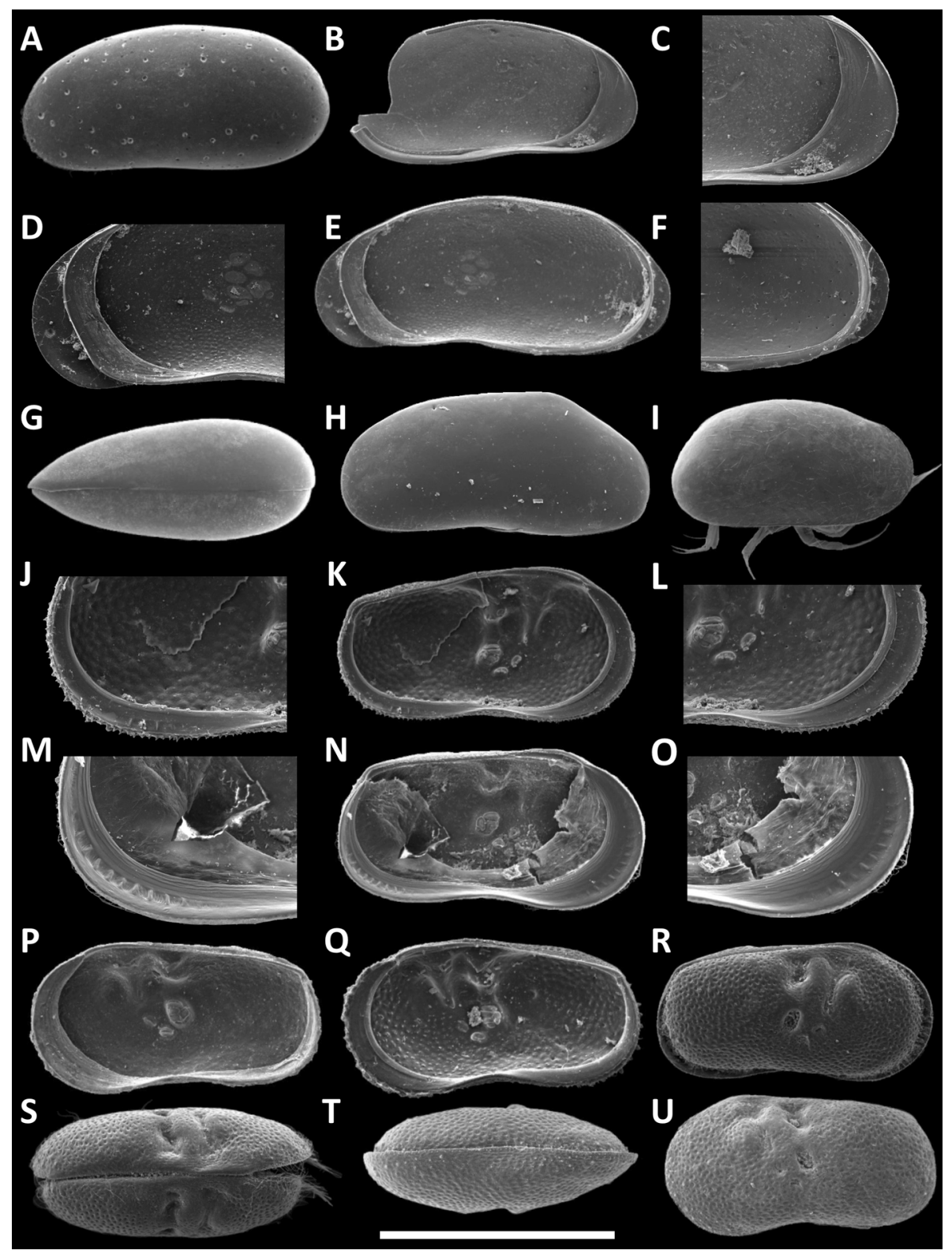

\section{Figure 2}

SEM photographs of Candonocypris novaezelandiae (A-F), Darwinula stevensoni (G), Fabaeformiscandona subacuta $(H)$, Isocypris beauchampi $(I)$, llyocypris gibba $(J-L, Q)$, and llyocypris getica $(M-P, R-U)$. A, C. novaezelandiae, female, carapace, left view (bar $=1221 \mu \mathrm{m})$; B, C. novaezelandiae, female, left valve inner view (bar $=1244 \mu \mathrm{m}) ; \mathrm{C}$, C. novaezelandiae, female, detail of left valve, anterior inner view $($ bar $=840 \mu \mathrm{m}) ; \mathrm{D}$, C. novaezelandiae, female, detail of right valve, anterior inner view (bar $=833 \mu \mathrm{m})$; $E$, C. novaezelandiae, female, right valve inner view (bar = $1120 \mu \mathrm{m}$ ); F, C. novaezelandiae, female, detail of right valve, posterior inner view (bar $=861 \mu \mathrm{m})$; $G$, D. stevensoni, female, carapace, dorsal view $($ bar $=544 \mu \mathrm{m}) ; \mathrm{H}, \mathrm{F}$. subacuta, female, carapace, left view $($ bar $=640 \mu \mathrm{m}) ; \mathrm{l}$, I. beauchampi, female, carapace, right view (bar = $1208 \mu \mathrm{m}$ ); J, llyocypris gibba, female, detail of left valve, posterior inner view (bar = $426 \mu \mathrm{m}) ; \mathrm{K}$, Ilyocypris gibba, female, left valve inner view (bar = $652 \mu \mathrm{m}) ; \mathrm{L}$, llyocypris gibba, female, detail of left valve, anterior inner view (bar = $438 \mu \mathrm{m}) ;$ M, llyocypris getica, female, detail of left valve, posterior inner view (bar $=438 \mu \mathrm{m})$; $N$, Ilyocypris getica, female, left valve inner view (bar = $828 \mu \mathrm{m})$; O, llyocypris getica, female, detail of left valve, anterior inner view (bar $=557 \mu \mathrm{m}) ;$, llyocypris getica, female, right valve inner view (bar $=789 \mu \mathrm{m})$; $Q$, llyocypris gibba, female, right valve inner view $($ bar = $629 \mu \mathrm{m}) ;$ R, llyocypris getica, female, carapace, right view (bar = $841 \mu \mathrm{m})$; S, llyocypris getica, female, carapace, dorsal view (bar = $895 \mu \mathrm{m})$; $T$, llyocypris getica, female, carapace, ventral view (bar = $725 \mu \mathrm{m})$; U, llyocypris getica, female, carapace, left view (bar $=789 \mu \mathrm{m}$ ). 


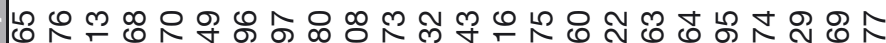

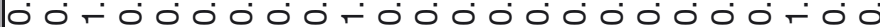

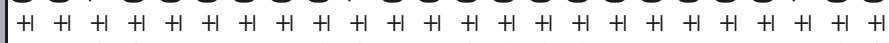
๒ิ

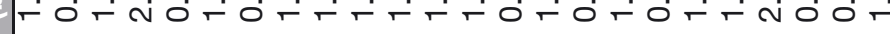

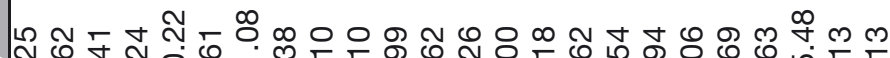

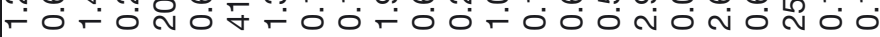
$+1+1+1+1+1+1+1+1+1+1+1+1+1+1+1+1+1+1+1+$

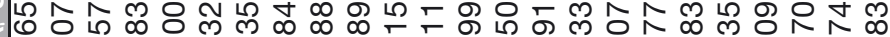
N

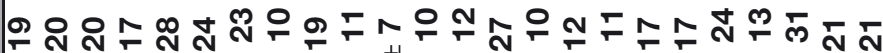

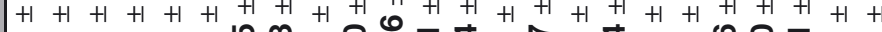

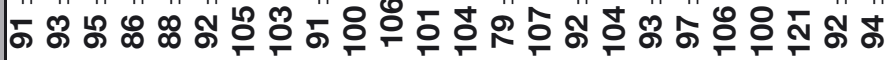

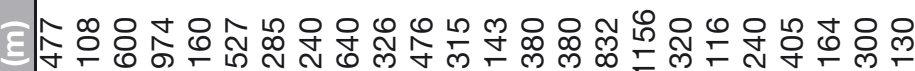

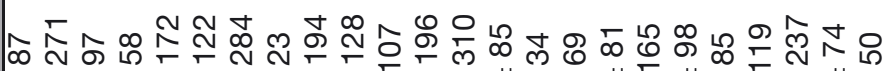
$+1+1+1+1+1+1+1+1+1+1+1+1+1+1-+1+1+1+1+1+1$

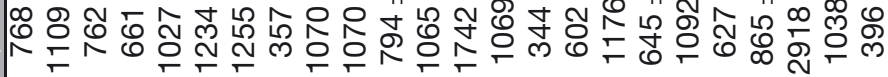

め) -

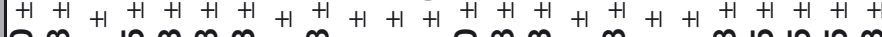

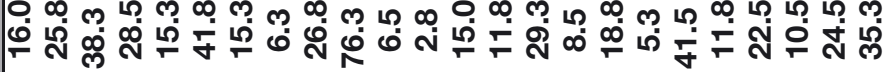

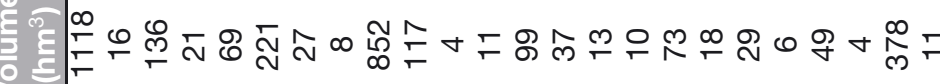

$\Leftrightarrow$ 윰ㄷำ mo N

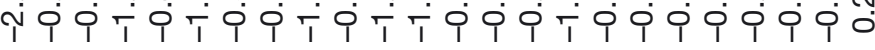

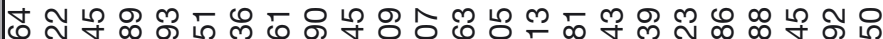

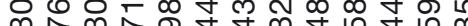
广ै

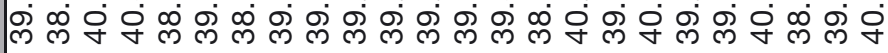

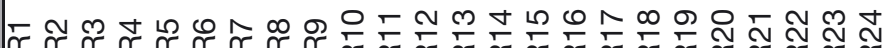

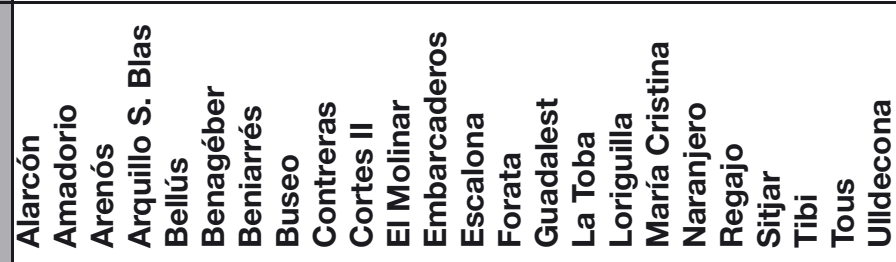




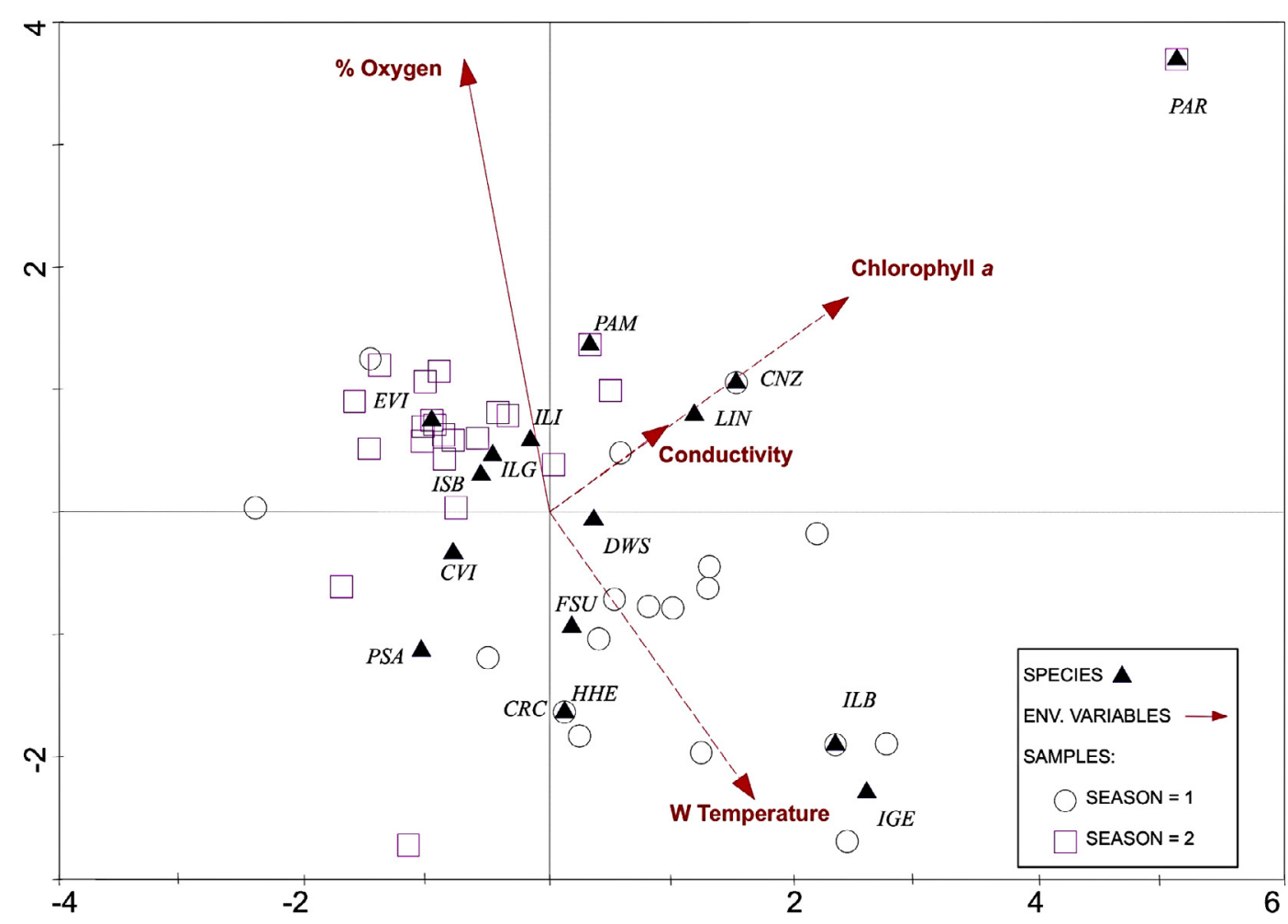

Figure 3

Canonical Correspondence Analysis (CCA) ordination diagram (first two axes) of ostracod species and reservoir samples in relation to the four most relevant variables according to the Forward Selection of Variables (FSV) permutation test. Species codes as in Table I. Arrows with solid line indicate significant variables, those with dashed line correspond to non significant variables $(p>0.05)$ according to FSV test. Season 1 = summer; Season 2 = winter.

value of dissimilarities within groups was 1000, being 1455 between groups (9999 permutations). The main seven species that together contributed to nearly $60 \%$ of the differences found are (in order of contribution) Herpetocypris brevicaudata, I. gibba, Cypridopsis vidua, Limnocythere inopinata, llyocypris inermis, Isocypris beauchampi and $D$. stevensoni. The last two species, together with I. gibba are more frequently found in reservoirs, in comparison to the others.

Further tests were performed in order to reveal the influence of sampling season (winter vs. summer). ANOSIM results show that there is a significant difference between the ostracod communities present in both seasons $(R=0.013, p=0.028)$, but only when taking into account alive specimens (i.e. excluding ostracod remains). When adding the valves and carapaces to this analysis no difference is found. According to SIMPER analysis, the mean rank value of dissimilarities within groups was 2265, being 2295 between groups (9999 permutations). Four species contributed to $61 \%$ of the differences between seasons. The species $I$. gibba and $I$. beauchampi were more frequent in winter while $D$. stevensoni and $F$. subacuta were more commonly found in summer.

CCA analyses resulted in a low relative amount of species data explained (first axis $5.0 \%$, second axis $4.4 \%$, and total inertia equal to 8.5 ), but high species-environment correlations (axis 1: 0.74 , axis $2: 0.70$ ). The only significant variable selected by FSV was oxygen saturation percentage. Figure 3 shows the ordination of the species and samples in relation to the four most relevant variables to allow an easier interpretation of the CCA results. To allow a better understanding of limnological variation in the reservoirs in relation to ostracod fauna, in addition to oxygen we added to the graph the variables temperature, conductivity and chlorophyll a concentration, which had the highest contribution (although not significant) according to FSV. 
Samples with highest oxygen saturation and lowest temperature, mainly corresponding to winter months, are dominated by the species I. gibba and I. beauchampi. On the other side of the diagram, $D$. stevensoni and $F$. subacuta are the most common species found in summer samples, characterised by highest temperatures and lowest oxygen. On the intermediate range of this gradient we found $C$. vidua and Pseudocandona albicans related to lower chlorophyll a values, while $L$. inopinata related to more eutrophic conditions.

\section{DISCUSSION}

In this paper we present the first comprehensive account of ostracods from reservoirs. Our results are remarkable in finding several species not previously recorded in the studied area; this confirms the first European records for C. novaezelandiae by Valls et al. (2013) and Escrivà (2011) (as "Cypridinae sp1"), which were found in coastal areas of Spain. The results of the present survey notably expand its known distribution to inland water bodies in the lberian Peninsula. As discussed in Valls et al. (2013), the species was previously found in Eastern Africa, Eastern Asia, Australia and New Zealand, but not in Europe. These findings suggest that this exotic species is expanding in the eastern Iberian Peninsula, in a similar way as another potential invader of Asian origin, F. subacuta (Escrivà et al., 2012), which has been found several times in the studied reservoirs. llyocypris getica is here reported for the first time in the Iberian Peninsula (see Baltanás et al., 1996 for a review of ostracod species in the area). The species is widely distributed in Northern Africa and European Mediterranean countries, although it has also been found as north as Germany (Meisch et al., 1996). These authors hypothesize that the presence of this species in Central Europe is attributable to passive transport by migratory birds. Notably, another common species in our survey, I. beauchampi, is also considered of African origin (Meisch, 2000; García-Berthou et. al., 2007). It can be argued that the on-going global warming could facilitate colonization of northern habitats by non-indigenous species coming mainly from Africa, through migratory birds stopping at the Iberian Peninsula in their routes. Among the most common ostracods in the studied reservoirs, we found $D$. stevensoni, a species with cosmopolitan distribution (Sohn, 1987; Karanovic, 2012), but see Schön et al. (2012) for a discussion of Darwinulidae cryptic species. Despite we found a relative high number of species in the studied reservoirs, it must be noticed that about half of the samples did not contain living specimens. According to the LR analysis, it is more probable to find alive ostracods in large, low nutrient content reservoirs, with high diversity of benthic invertebrates. This is in agreement with general aspects of reservoir limnology, in which anoxic conditions are common in the hypolimnion, affecting negatively the proliferation of benthic fauna, particularly in small and highly fluctuating dam lakes (Margalef, 1983).

Although the majority of these reservoirs were built during the $20^{\text {th }}$ century, and are connected to natural rivers, their associated benthic fauna is markedly different from these streams, as we have shown for the particular group of Ostracoda, and as expected from previous findings on zooplankton in other areas (e.g. Akopian et al., 1999). Notwithstanding the potential changes in riverine communities that may have occurred taking into account the temporal gap between river (Mezquita et al., 1999) and reservoir sampling campaigns compared in the present work, we would expect certain resilience of the ostracod assemblages for such a period of ten years, particularly when these basins have experienced no major impacts during this time interval. Consequently, we could conclude that the type of habitat, i.e. lotic vs. lentic has a strong influence on the community composition of limnetic ostracods, as already observed in previous works (Carbonel, 1988; Smith and Delorme, 2009; Mesquita-Joanes et al., 2012).

Seasonality in Mediterranean aquatic habitats has been characterised as one of the main driving factors related to community changes through the year (Florencio et al., 2009). Although reservoirs are non-natural environments managed depending on human needs, they also suffer strong level fluctuations as a result of river input changes related to the seasonality of the Mediterranean climate, which are exacerbated by human consumption of water during 
summer. In addition to these level changes of natural origin, human management trying to keep water level constant and as high as possible, also affect the ostracod communities of the reservoirs. These fluctuations lead to the summer dominance of species tolerant to low oxygen and high temperature and trophic state, such as D. stevensoni (Rossi et al., 2002) and $F$. subacuta (Escrivà et al., 2012), rather than species colonizing from upstream rivers. This duality, functioning both as deep permanent lakes in the centre and temporary habitats at littoral areas, allows the presence of ostracod species such as Eucypris virens or I. gibba during wet periods (from fall to spring), which show more preferences for temporary waters (Meisch, 2000; Martins et al., 2009).

Reservoirs in Mediterranean areas are likely to play the role of stepping-stones for exotic ostracod species, due to their completely different environmental parameters in relation to the river to which they are connected. As the Iberian Peninsula has a very low number of natural inland large permanent lakes, reservoirs can facilitate the colonization of the area by species typical of such habitats, originating from other European areas, Africa or other regions. Previous studies have shown how, despite holding a low number of species due to their disturbed state and dynamics (Prat et al., 1992), reservoirs allow the colonization of the Iberian Peninsula by previously unrecorded species of crustaceans (Riera et al., 1992).

The colonization of reservoirs by invertebrates, beside river connections, can be driven among other vectors, by humans and aquatic birds (Bilton et al., 2001), that can feed, rest and nest in a diversity of waterbodies, including coastal wetlands, ricefields and nearby reservoirs. Birds are well-known dispersal agents of aquatic invertebrates: they have the ability to transport propagules and living adults, either as mud adhered to their legs and or in their faeces (Figuerola and Green, 2002; Frisch et al., 2007). Birds should therefore be regarded as possible dispersal vectors for exotic species present in reservoirs, which can be coming from the nearby ricefields, a type of habitat that has been recognised as specially suitable for exotic ostracods (Forés et al., 1986; McKenzie and Moroni, 1986; Escrivà et al., 2012).

In this study we have shown how reservoirs can be a new and suitable habitat for the colonization of exotic species of ostracods in the frame of the Mediterranean area. Alien species originating in warmer areas (tropical Asia or Northern Africa) could spread more rapidly in Southern Europe due mainly to the influence of global warming and helped by transport vectors such as birds or humans. Further research is needed in reservoirs of the lberian Peninsula and other European regions to check whether the common presence of exotic ostracods is also found in different climate and limnological conditions.

\section{ACKNOWLEDGEMENTS}

The authors would like to thank the microscope unit of the SCSIE-University of Valencia for their support with ostracod SEM pictures. This work was partially funded by the Spanish Ministry of Science and Innovation project ECOINVADER (CGL2008-01296/BOS) and the University of Valencia ("V-Segles" predoctoral grant to A. Escrivà). We would like to thank C. Rojo (Univ. Valencia) and the CHJ for help in organising the collection of samples and environmental data, and two anonymous referees that suggested helpful improvements to an earlier version of the manuscript.

\section{REFERENCES}

Akopian M., Garnier J. and Pourriot R., 1999. A large reservoir as source of zooplankton for the river: structure of the populations and influence of fish predation. J. Plankton Res., 21, 285-297.

Aupí V., 2005. Guía del clima de España, Omega, Barcelona, 336 p.

Baltanás A., Beroiz B. and López A., 1996. Lista faunística y bibliográfica de los ostrácodos no-marinos (Crustacea, Ostracoda) de la Península Ibérica, Islas Baleares e Islas Canarias. Listas de la Flora y Fauna de las aguas continentales de la Península Ibérica, Publicación No 12, Asociación Española de Limnología, Madrid, $71 \mathrm{p}$. 
Bilton D.T., Freeland J.R. and Okamura B., 2001. Dispersal in freshwater invertebrates. Annu. Rev. Ecol. Syst., 32, 159-181.

Carbonel P., 1988. Ostracods and the transition between fresh and saline waters. In: De Deckker P., Colin J.P. and Peypouquet J.P. (eds.), Ostracoda in the Earth Sciences, Elsevier, Amsterdam, 157-173.

Clarke K.R. and Warwick R.M., 2001. Change in marine communities: an approach to statistical analysis and interpretation, 2nd edn. PRIMER-E, Plymouth, $172 \mathrm{p}$.

Durán C., Touya V., Anadón A. and Lanao M., 2009. Afección y control del mejillón cebra en la cuenca del Ebro. Tecnol. Agua, 307, 20-28.

Durán C., Lanao M., Pérez L.P., Chica C., Anadón A. and Touya V., 2012. Estimación de los costes de la invasión del mejillón cebra en la cuenca del Ebro (periodo 2005-2009). Limnetica, 31, 213-230.

Durán Lalaguna C. and Anadón Marco A., 2008. The zebra mussel invasion in Spain and navigation rules. Aq. Invasions, 3, 315-324.

Elvira B., 1995. Native and exotic freshwater fishes in Spanish basins. Freshwater Biol., 33, 103-108.

Escrivà A., 2011. Biodiversitat del zooplàncton i microzoobentos a les aigues continentals de Vinaròs $i$ el Baix Maestrat, Antinea, Vinaròs, 98 p.

Escrivà A., Smith R., Aguilar-Alberola J.A., Kamiya T., Karanovic I., Rueda J., Shornikov E.I. and Mesquita-Joanes F., 2012. Global distribution of Fabaeformiscandona subacuta: an exotic invasive Ostracoda in the Iberian Peninsula? J. Crustacean Biol., 32, 949-961.

Figuerola J. and Green A.J., 2002. Dispersal of aquatic organisms by waterbirds: a review of past research and priorities for future studies. Freshwater Biol., 47, 483-494.

Florencio M., Serrano L., Gómez-Rodríguez C., Millán A. and Díaz-Paniagua C., 2009. Inter- and intraannual variations of macroinvertebrate assemblages are related to the hydroperiod in Mediterranean temporary ponds. Hydrobiologia, 634, 167-183.

Forés E., Menéndez M. and Comín F.A., 1986. Contribución al conocimiento de crustáceos y rotíferos del Delta del Ebro. Misc. Zool., 10, 105-111.

Frisch D., Green A.J. and Figuerola J., 2007. High dispersal capacity of a broad spectrum of aquatic invertebrates via waterbirds. Aquat. Sci. 69,568-574.

García-Berthou E., Boix D. and Clavero M., 2007. Non-indigenous animal species naturalized in Iberian inland waters. In: Gherardi F. (ed.), Biological invaders in inland waters: profiles, distribution, and threats, Springer, Dordrecht, 123-140.

Geiger G., Alcorlo P., Baltanás A. and Montes C., 2005. Impact of an introduced Crustacean on the trophic webs of Mediterranean wetlands. Biol. Invasions, 7, 49-73.

Gherardi F., 2007. Biological invasions in inland waters: an overview. In: Gherardi F. (ed.), Biological invaders in inland waters: profiles, distribution and threats, Springer, Dordrecht, 3-26.

Hammer $\varnothing$., Harper D.A.T. and Ryan P.D., 2001. PAST: Paleontological statistics software package for education and data analysis. Palaeontol. Electron., 4, 1-9.

Havel J.E., Lee C.E. and Zanden M.J.V., 2005. Do reservoirs facilitate invasions into landscapes? Bioscience, 55, 518-525.

Karanovic I., 2012. Recent freshwater ostracods of the world. Crustacea, Ostracoda, Podocopida, Springer, New York, 608 p.

Lepš J. and Šmilauer P., 2003. Multivariate analysis of ecological data using CANOCO, Cambridge Univ. Press, Cambridge, 269 p.

Margalef R., 1983. Limnología, Omega, Barcelona, 1010 p.

Martins M.J.F., Vandekerkhove J., Mezquita F., Schmit O., Rueda J., Rossetti G. and Namiotko T., 2009. Dynamics of sexual and parthenogenetic populations of Eucypris virens (Crustacea: Ostracoda) in three temporary ponds. Hydrobiologia, 636, 219-232.

McKenzie K.G. and Moroni A., 1986. Man as an agent of crustacean passive dispersal via useful plants exemplified by Ostracoda ospiti esteri of the Italian ricefiels ecosystem - and implications arising therefrom. J. Crustacean Biol., 6, 181-198.

Meisch C., 2000. Freshwater Ostracoda of Western and Central Europe, Spektrum Akademischer Verlag $\mathrm{GmbH}$, Heidelberg, Berlin, $522 \mathrm{p}$.

Meisch C., Fuhrmann R. and Wouters K., 1996. Ilyocypris getica Masi, 1906 (Crustacea, Ostracoda): taxonomy, ecology, life history, distribution, fossil occurrence and first record for Germany. Trav. Sci. Mus. Nat. Hist. Nat. Lux., 23, 3-28. 
Mesquita-Joanes F., Smith A.J. and Viehberg, F., 2012. The ecology of Ostracoda across levels of biological organisation from individual to ecosystem: a review of recent developments and future potential. In: Horne D.J., Holmes J.A., Rodríguez-Lázaro J. and Viehberg F. (eds.), Ostracoda as proxies for Quaternary climate change, Developments in Quaternary Science Series, 17. Elsevier, Amsterdam, 15-35.

Mezquita F., Griffiths H.I., Sanz S., Soria J.M. and Piñón A., 1999. Ecology and distribution of ostracods associated with flowing waters in the eastern Iberian Peninsula. J. Crustacean Biol., 19, 344-354.

Mezquita, F., Griffiths H.I., Domínguez M.I. and Lozano-Quilis M.A., 2001. Ostracoda (Crustacea) as ecological indicators: a case study from Iberian Mediterranean brooks. Archiv. Hydrobiol., 150, 545-560.

MMAMRM, 2011. Pest Risk Analysis on the introduction of Pomacea insularum (d'Orbigny, 1835) into the EU, Unpublished report, Ministerio de Medio Ambiente y Medio Rural y Marino, 45 p.

Moss B., 1998. Ecology of fresh waters, 3rd ed., Blackwell Science, Oxford, 557 p.

Pérez-Quintana J.C., 2008. Revision of the distribution of Corbicula fluminea (Müller, 1774) in the Iberian Peninsula. Aquat. Invasions, 3, 355-358.

Prat N., Real M. and Rieradevall M., 1992. Benthos of Spanish lakes and reservoirs. Limnetica, 8, 221-229.

Riera J.L., Jaume D., de Manuel J., Morgui J.A. and Armengol J., 1992. Patterns of variation in the limnology of Spanish reservoirs: a regional study. Limnetica, 8, 11-123.

Rossi V., Todeschi E.B.A, Gandolfi A., Invidia M. and Menozzi P., 2002. Hypoxia and starvation tolerance in individuals from a riverine and lacustrine population of Darwinula stevensoni (Crustacea: Ostracoda). Arch. Hydrobiol., 154, 151-171.

Schön I., Pinto R.L., Halse S., Smith A.J., Martens K. and Birky Jr. C.W., 2012. Cryptic species in putative ancient asexual darwinulids (Crustacea, Ostracoda). PLoS ONE 7, e39844.

Smith A.J. and Delorme L.D., 2009. Ostracoda, In: Thorp J. and Covich A. (eds.), Ecology and classification of North American freshwater invertebrates, 3rd edn., Academic Press, London, 811-849.

Sohn I.G., 1987. The ubiquitous ostracode Darwinula stevensoni (Brady and Robertson, 1870), redescription of the species and lectotype designation. Micropaleontology, 33, 150-163.

SPPS Inc., 2010. 15.0 Brief Guide SPPS, SPPS Inc., Chicago, 179 p.

Tachet H., Richoux P., Bournaud M. and Usseglio-Polatera P., 2000. Invertébrés d'eau douce. Systématique, biologie, écologie. CNRS Editions, Paris, 588 p.

ter Braak C.J.F. and Šmilauer P., 2002. CANOCO Reference manual and CanoDraw for Windows user's guide: software for canonical community ordination (version 4.5), Microcomputer Power, Ithaca, $500 \mathrm{p}$.

Valls L., Rueda J. and Mesquita-Joanes F., 2013. Dynamics of Ostracoda (Crustacea) assemblages in a Mediterranean pond system (Racó de l'Olla, Albufera Nat. Park) with focus on the exotic species Candonocypris novaezelandiae (Baird, 1843). Ann. Limnol. - Int. J. Lim. 49, 237-247. 